\title{
Anti-a-amino-3-hydroxy-5-methyl-4- isoxazolepropionic acid receptor GluR2 encephalitis in a myasthenia gravis patient with complete thymectomy: a case report
}

\author{
Qingyang Luo ${ }^{1}$, Xianghong $\mathrm{Wu}^{2}$ and Wen Huang ${ }^{1 *}$ (D)
}

\begin{abstract}
Background: Autoimmune encephalitis (AE) is a newly recognized autoimmune disorders in which the targets are proteins or receptors involved in synaptic transmission and neuronal excitability. a-amino-3-hydroxy-5-methyl-4isoxazolepropionic acid receptor (AMPAR) is a subtype of glutamate receptor that mediates most of the fast excitatory neurotransmission in the brain.

Case presentation: A 50-year-old woman presented with subacute onset of memory loss and behavioral changes. High levels of serum (1:1000) and CSF (1:32) antibodies against the AMPAR GluR2 were detected. A wide range of abnormalities in $6-8 \mathrm{~Hz}$ low to middle slow waves was found by electroencephalographs, and high-intensity signals on fluid-attenuated inversion recovery in both the medial temporal lobe and hippocampus were identified on brain magnetic resonance images. This patient presented with myasthenia gravis and type B2 thymoma (World Health Organization Thymoma Classification) at age 48. This case was unique in that the patient initiated with the symptom of myasthenia gravis and thymoma two years prior to encephalitis, and a complete thymectomy was performed before AE onset without recurrence of the thymoma when encephalitis occurred.

Conclusions: Thymoma was reported to be associated with paraneoplastic neurological disease. This is the first time a thymectomy has been applied in a myasthenia gravis patient with thymoma two years prior to the onset of anti-AMPAR2 encephalitis. This case highlights the complexity of autoimmune encephalitis associated with thymoma.
\end{abstract}

Keywords: Autoimmune encephalitis, a-Amino-3-hydroxy-5-methyl-4-isoxazolepropionic acid receptor, Thymoma, Myasthenia gravis

\section{Background}

Autoimmune encephalitis (AE), which is characterized by the subacute (days to weeks) development of seizures, recent memory loss, mental confusion and psychiatric symptoms due to antibodies against neuronal cell surface and synaptic proteins, is newly recognized autoimmune disorders involved in synaptic transmission and neuronal excitability [1]. Although thymoma or thymic carcinoma has been

\footnotetext{
*Correspondence: hwen1229@163.com

1 Department of Neurology, The First Affiliated Hospital of Guangxi Medical

University, \#6 Shuangyong Road, Nanning 530021, Guangxi, China

Full list of author information is available at the end of the article
}

reported to be associated with $\mathrm{AE}$, the most common targets are LGI1, Caspr2 and $\gamma$-aminobutyric acid (GABA) - A type receptor antibody encephalitis [2-5]. Thymoma-associated encephalitis associated with $\alpha$-amino-3-hydroxy-5-methyl-4-isoxazolepropionic acid receptor (AMPAR), one of neuronal surface autoantigens, is rare [6]. In this report, we describe a female thymomatous myasthenia gravis (MG) patient with AMPAR encephalitis onset after a complete thymectomy without recurrence of the thymoma.

(c) The Author(s). 2019 Open Access This article is distributed under the terms of the Creative Commons Attribution 4.0 International License (http://creativecommons.org/licenses/by/4.0/), which permits unrestricted use, distribution, and reproduction in any medium, provided you give appropriate credit to the original author(s) and the source, provide a link to the Creative Commons license, and indicate if changes were made. The Creative Commons Public Domain Dedication waiver (http://creativecommons.org/publicdomain/zero/1.0/) applies to the data made available in this article, unless otherwise stated. 


\section{Case presentation}

A 50-year-old woman presenting with subacute onset of memory loss and behavioral changes lasting for one month was admitted to our hospital on July 9, 2018. On examination, she was confused and apathetic, disoriented to time and space with impaired memory and executive dysfunction, slurred speech with partly comprehensive aphasia, and urinary and fecal incontinence when she was admitted to our hospital. She was poorly collaborative in Mini-Mental State Examination (MMSE). No localized symptoms or signs were observed.

Two years ago, this patient presented at age 48 with right ptosis. She was diagnosed with MG based on positive $\mathrm{AChR} \mathrm{Ab}$ (titre $>20 \mathrm{nmol} / \mathrm{L}$ ) and a neostigmine test, as well as a decrement of $15 \%$ in low frequency (3 $\mathrm{Hz}$ ) repetitive nerve stimulation on orbicularis oculi muscles, trapeziuses and deltoid muscles. A computerized tomography $(\mathrm{CT})$ chest showed a thymoma (3.1 $\mathrm{cm} \times 1.9 \mathrm{~cm}$ ), which was resected on August 22, 2016 (Fig. 1a). Histological examination showed WHO type B2: Kpan(+++), CK19(+++), CD30(+++), CD20(-), CD3(-), CD5(+), TdT(+), and Ki67(+, 90\%). Whole-body bone scans by emission computed tomography were normal. Space-occupying lesions were not found in the liver, kidneys or subclavian area investigated with Bultrasound. For the next two years, the patient's symptoms were well-controlled with pyridostigmine treatment.

Routine serum analyses were within the normal range, including thyroid hormones and associated antibodies, anti-nuclear antibody, and anti-dsDNA. Polymerase chain reaction (PCR) for herpes simplex virus, cytomegalovirus, influenza virus, enterovirus, and measles virus in serum were also negative. Cell count, protein, glucose and chloride were normal in the cerebrospinal fluid (CSF). CSF and serum were negative for oligoclonal bands. Antibodies against cell surface or synaptic proteins were assessed in serum and CSF obtained before immunotherapy using transfected HEK-293 cells by the indirect immunofluorescence method (Kindstar Global, Wu Han, China) showed high levels of serum (1:1000) and CSF (1:32) antibodies against the AMPAR GluR2 (AMPAR2, Fig. $2 b$ and d). A wide range of abnormalities in $6-8 \mathrm{~Hz}$ low to middle slow waves was found by electroencephalographs (EEGs). Brain magnetic resonance images (MRI) identified high-intensity signals on fluidattenuated inversion recovery (Flair) in both the medial temporal lobe and hippocampus on June 25, 2018 (Fig. 3) . Antibodies against $\alpha$-amino-3-hydroxy-5-methyl-4-isoxazolepropionic acid (AMPA) GluR1, N-methyl-D-aspartate receptor, GABA B type receptor, leucine-rich glioma inactivated protein 1 (LGI1) and Caspr2 were negative. The chest CT was normal without thymoma recurrence after thymectomy on July 11, 2018 (Fig. 1b). Ultrasounds of the liver, pancreas, spleen, kidney, bladder, ovary and uterus, as well as serological tumor markers, were also normal and did not reveal a neoplasm. Anti-AMPAR2 encephalitis was thus diagnosed. Intravenous methylprednisolone $(1 \mathrm{~g} /$ day for 3 days and $500 \mathrm{mg} /$ day for 3 days) followed by oral prednisolone $(1 \mathrm{mg} / \mathrm{kg} /$ day) was administered with slow tapering. The patient's symptoms did not have significant remission, and azathioprine $(50 \mathrm{mg}$ twice a day) was applied when she was discharged on July 20,2018 . A neuropsychological exam showed memory deficit, calculative and comprehensive dysfunction, lack of motivation and social emotion and urinary incontinence.

The patient had voluntary urinary control, and the initial MRI lesions resolved in 16 days (July 11, 2018). The patient only had mild long-time memory deficits and a good recovery with an MMSE score of 24 at follow-up on September 13, 2018.

\section{Discussion}

AMPAR is a subtype of glutamate receptor that mediates most of the fast excitatory neurotransmission in the brain. The majority of AMPAR are tetramers composed of GluR1, 2, 3 or 4 subunits. A high level of GluR1/2 and GluR2/3 receptors is found in the synaptic CA3-CA1 areas of the hippocampus followed by the subiculum, cerebellum, caudate-putamen, and cerebral cortex [7].
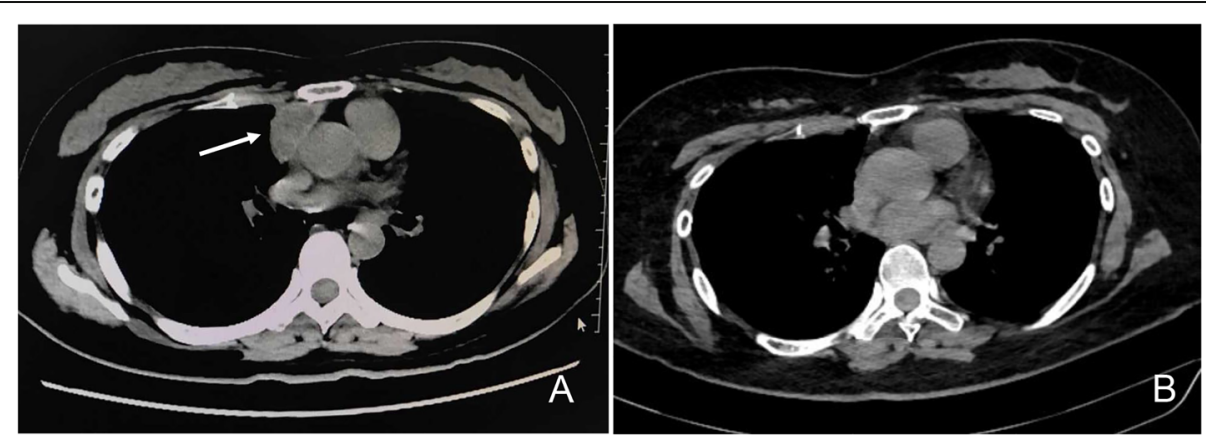

Fig. 1 Chest CT showed a $3.1 \mathrm{~cm} \times 1.9 \mathrm{~cm}$ thymoma on August 3, 2016 (a) and was normal without thymoma recurrence after thymectomy on July 11,2018 (b) 


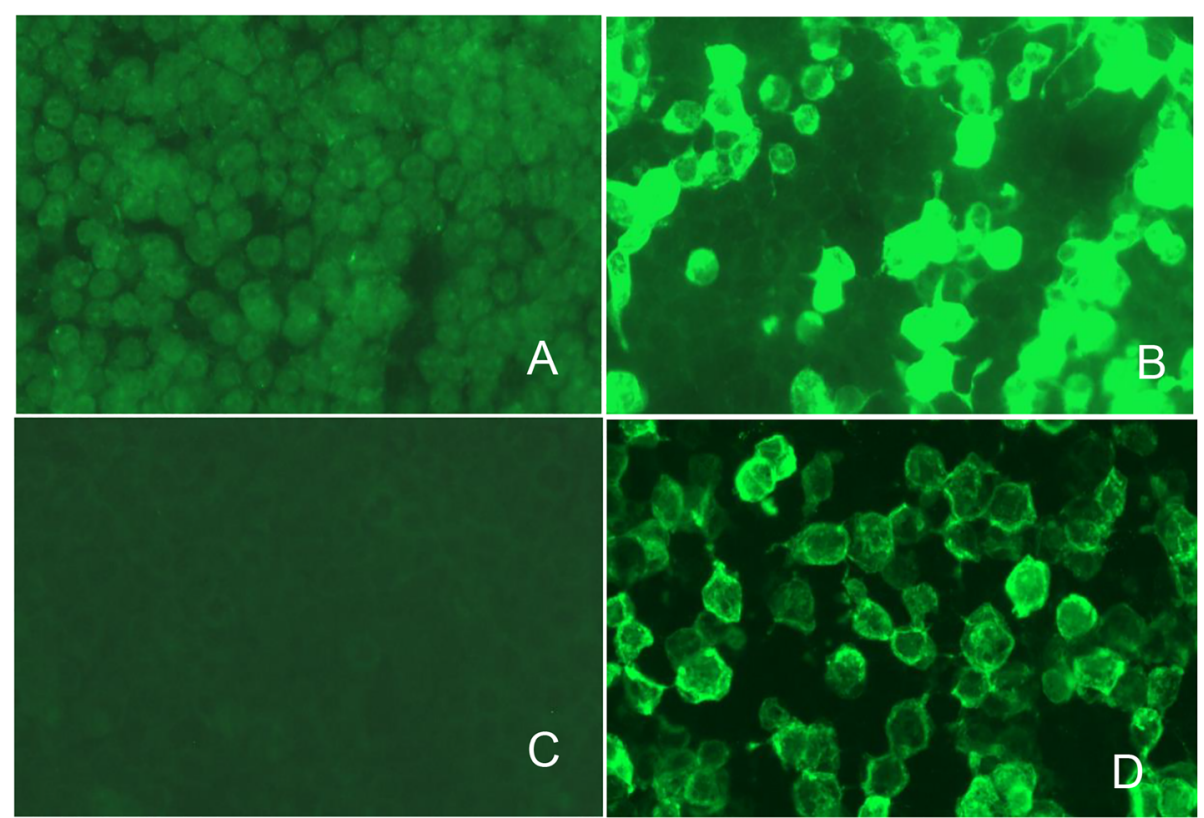

Fig. 2 Neuroimmunological investigations showed high levels of serum $(1: 1000, \mathbf{b})$ and $\operatorname{CSF}(1: 32$, d) antibodies against the AMPAR GluR2. a and $\mathbf{c}$ were serum and CSF negative control respectively

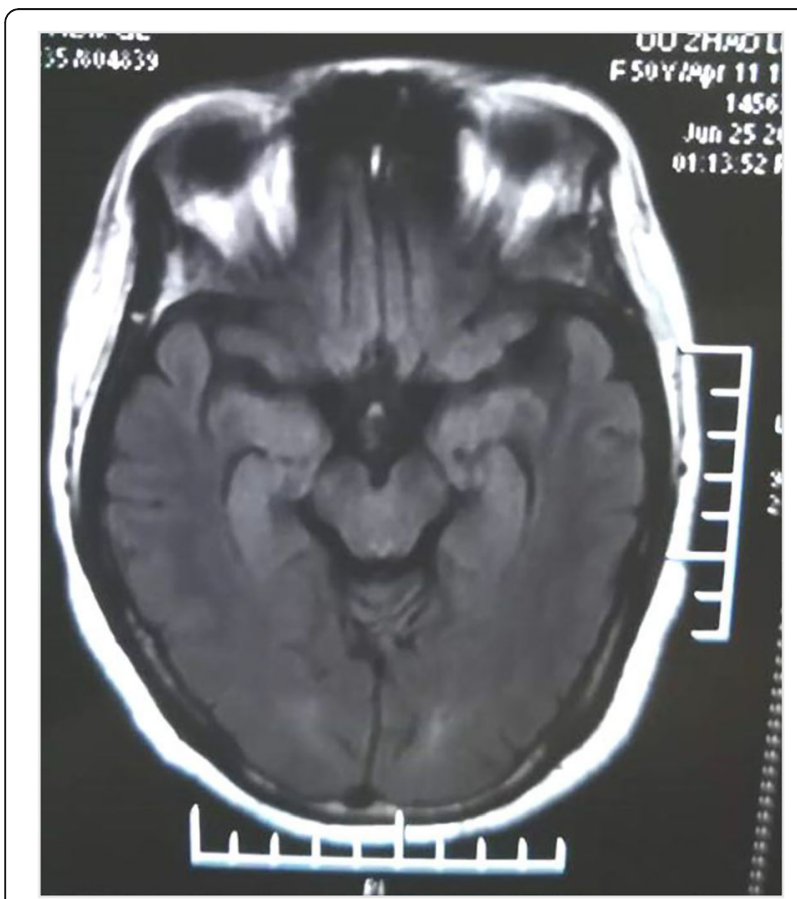

Fig. 3 Brain MRI performed on June 25, 2018 identified highintensity signals on fluid-attenuated inversion recovery in both the medial temporal lobe and hippocampus
The thymus is a central organ for the development of the immune system, particularly for the selection of $\mathrm{T}$ cells with appropriate self-tolerance [8]. It is not surprising that thymoma is considered to be a possible initiator for most paraneoplastic neurological disease, such as AE [8]. In 2009, Lai [7] first reported three patients with antiAMPAR encephalitis, and thymoma were identified among 109 cases of limbic encephalitis. To date, eleven cases of thymoma-associated anti-AMPAR2 encephalitis have been described in six publications (Table 1) [6, 7, 9-12]. In most cases, thymoma was detected in oncological screening with the first episode of encephalitis, though a malignant thymoma treated with radiotherapy and chemotherapy six years prior to encephalitis was found in one case [9]. Our case was unique in that the patient initiated with the symptom of myasthenia gravis and thymoma two years prior to $\mathrm{AE}$, and a complete thymectomy was performed before $\mathrm{AE}$ onset without recurrence of the thymoma when AE occurred. Recently, a patient with anti-AMPAR encephalitis who was reported to be in remission for 34 months showed clinical relapse three months after the detection of recurrent thymoma [11]. Hor et al. reported a case of thymoma-associated myasthenia gravis and LGI1encephalitis with nephrotic syndrome after thymectomy [13]. Our case raises the questions of whether the autoantigens could be expressed by the thymus after thymectomy, and how these autoantigens from thymic tumors could trigger immune disorders. It is probable that these autoantigens were expressed by the thymus at an early stage before thymectomy and existed in the central 
Table 1 Relation of thymoma and outcome in patients with anti-AMPAR encephalitis

\begin{tabular}{|c|c|c|c|c|c|c|c|}
\hline Case & $\begin{array}{l}\text { sex/ } \\
\text { age }\end{array}$ & Tumor & $\begin{array}{l}\text { Time from symptoms } \\
\text { of AE to tumor } \\
\text { diagnosis }\end{array}$ & $\begin{array}{l}\text { Other } \\
\text { autoimmune } \\
\text { or antibodies }\end{array}$ & Treatment & Outcome & Reference \\
\hline 1 & $F / 44$ & $\begin{array}{l}\text { Thymic } \\
\text { carcinoma }\end{array}$ & $\begin{array}{l}\text { Concurrent with first } \\
\text { episode of encephalitis }\end{array}$ & $\begin{array}{l}\text { ANA, dsDNA, } \\
\text { cardiolipin } \\
\text { antibodies }\end{array}$ & $\begin{array}{l}\text { Tumor removal. At } \\
\text { presentation and relapse: } \\
\text { IVlg, corticosteroids. Chronic } \\
\text { treatment with azathioprine. }\end{array}$ & $\begin{array}{l}\text { First episode: returned to baseline. } \\
\text { Subsequent relapsing: memory deficit. } \\
\text { Residual short-term memory deficit } \\
\text { after 3rd relapse. }\end{array}$ & $\begin{array}{l}\text { Lai et al. } \\
2009\end{array}$ \\
\hline 2 & $\begin{array}{l}M / \\
38\end{array}$ & $\begin{array}{l}\text { Malignant } \\
\text { thymoma }\end{array}$ & $\begin{array}{l}\text { Concurrent with relapse } \\
\text { of encephalitis }\end{array}$ & $\begin{array}{l}\text { GAD } \\
\text { antibodies }\end{array}$ & $\begin{array}{l}\text { Tumor removal, radiation } \\
\text { therapy, corticosteroids, } \\
\text { plasma exchange, IVlg }\end{array}$ & $\begin{array}{l}\text { First episode: returned to baseline. } \\
\text { Mild residual memory deficit after } \\
\text { relapse; steroid dependant muscle } \\
\text { spasms and rigidity. }\end{array}$ & $\begin{array}{l}\text { Lai et al. } \\
2009\end{array}$ \\
\hline 3 & $F / 44$ & Thymoma & $\begin{array}{l}\text { Concurrent with first } \\
\text { episode of encephalitis }\end{array}$ & $\begin{array}{l}\text { CV2/CRMP5 } \\
\text { antibodies }\end{array}$ & N/A & $\begin{array}{l}\text { Unexpected death due to } \\
\text { cardiorespiratory arrest. }\end{array}$ & $\begin{array}{l}\text { Lai et al. } \\
2009\end{array}$ \\
\hline 4 & $F / 60$ & $\begin{array}{l}\text { Malignant } \\
\text { thymoma }\end{array}$ & $\begin{array}{l}\text { Six years before first } \\
\text { episode of encephalitis } \\
\text { with residual thymoma } \\
\text { without evidence of } \\
\text { relapse. }\end{array}$ & None & $\begin{array}{l}\text { Radiotherapy and } \\
\text { chemotherapy six years } \\
\text { before AE without } \\
\text { thymectomy. At } \\
\text { presentation: corticosteroids }\end{array}$ & Complete recovery & $\begin{array}{l}\text { Graus et al. } \\
2010\end{array}$ \\
\hline 5 & $F / 47$ & $\begin{array}{l}\text { Thymoma } \\
\text { (WHO } \\
\text { type B1) }\end{array}$ & $\begin{array}{l}\text { Concurrent with first } \\
\text { episode of encephalitis }\end{array}$ & $\begin{array}{l}\text { anti-AchR } \\
\text { and titin } \\
\text { antibodies }\end{array}$ & $\begin{array}{l}\text { Corticosteroid at first } \\
\text { episode. Corticosteroid, } \\
\text { azathioprine and tumor } \\
\text { removal when relapse. }\end{array}$ & $\begin{array}{l}\text { First episode: short term memory } \\
\text { deficit, severe anomic aphasia, } \\
\text { executive dysfunction.Mild anomic } \\
\text { aphasia and bulbar symptoms when } \\
\text { relapse. }\end{array}$ & $\begin{array}{l}\text { Li et al. } \\
2015\end{array}$ \\
\hline 6 & $\begin{array}{l}62 / \\
M\end{array}$ & $\begin{array}{l}\text { Malignant } \\
\text { thymoma }\end{array}$ & $\begin{array}{l}\text { Concurrent with first } \\
\text { episode of encephalitis }\end{array}$ & None & $\begin{array}{l}\text { Tumor removal, } \\
\text { corticosteroid, IVlg }\end{array}$ & Full treatment response & $\begin{array}{l}\text { Höftberger } \\
\text { et al. } 2015\end{array}$ \\
\hline 7 & $\begin{array}{l}23 / \\
M\end{array}$ & Thymoma & $\begin{array}{l}\text { Concurrent with first } \\
\text { episode of encephalitis }\end{array}$ & None & $\begin{array}{l}\text { Tumor removal, IVIg, } \\
\text { corticosteroid, rituximab }\end{array}$ & Partial treatment response & $\begin{array}{l}\text { Höftberger } \\
\text { et al. } 2015\end{array}$ \\
\hline 8 & $53 / F$ & $\begin{array}{l}\text { Malignant } \\
\text { thymoma }\end{array}$ & $\begin{array}{l}\text { Concurrent with first } \\
\text { episode of encephalitis }\end{array}$ & CRMP5 & $\begin{array}{l}\text { Tumor removal, } \\
\text { chemotherapy, } \\
\text { radiotherapy, } \\
\text { corticosteroid, IVlg }\end{array}$ & No treatment response & $\begin{array}{l}\text { Höftberger } \\
\text { et al. } 2015\end{array}$ \\
\hline 9 & $\begin{array}{l}71 / \\
M\end{array}$ & $\begin{array}{l}\text { Thymic } \\
\text { carcinoid }\end{array}$ & $\begin{array}{l}\text { Concurrent with first } \\
\text { episode of encephalitis }\end{array}$ & NMDAR & $\begin{array}{l}\text { Tumor removal, } \\
\text { corticosteroid, plasma } \\
\text { exchange }\end{array}$ & Full treatment response & $\begin{array}{l}\text { Höftberger } \\
\text { et al. } 2015\end{array}$ \\
\hline 10 & $\begin{array}{l}21 / \\
M\end{array}$ & $\begin{array}{l}\text { Thymic } \\
\text { carcinoid }\end{array}$ & $\begin{array}{l}\text { Concurrent with first } \\
\text { episode of encephalitis }\end{array}$ & None & $\begin{array}{l}\text { Tumor removal, } \\
\text { chemotherapy, } \\
\text { radiotherapy, } \\
\text { corticosteroid, IVlg }\end{array}$ & $\begin{array}{l}\text { Mild deficits in working memory } \\
\text { persisted at } 18 \text { months after disease } \\
\text { onset. }\end{array}$ & $\begin{array}{l}\text { Joubert et } \\
\text { al. } 2015\end{array}$ \\
\hline 11 & $F / 34$ & $\begin{array}{l}\text { Thymoma } \\
\text { (WHO } \\
\text { type B3) }\end{array}$ & $\begin{array}{l}\text { Concurrent with first } \\
\text { episode of encephalitis; } \\
\text { Recurrence with clinical } \\
\text { relapse }\end{array}$ & None & $\begin{array}{l}\text { Corticosteroid and tumor } \\
\text { removal at first episode. } \\
\text { Corticosteroid and } \\
\text { resection of the recurrent } \\
\text { tumor after relapse. }\end{array}$ & $\begin{array}{l}\text { First episode: depressive symptoms. } \\
\text { Memory deficits after relapse. }\end{array}$ & $\begin{array}{l}\text { Omi et al. } \\
2018\end{array}$ \\
\hline 12 & $\mathrm{~F} / 50$ & $\begin{array}{l}\text { Thymoma } \\
\text { (WHO } \\
\text { type B2) }\end{array}$ & $\begin{array}{l}2 \text { years before first } \\
\text { episode of encephalitis }\end{array}$ & $\begin{array}{l}\text { anti-AchR } \\
\text { antibodies }\end{array}$ & $\begin{array}{l}\text { Tumor removal } 2 \text { years } \\
\text { before AE. Corticosteroid } \\
\text { and azathioprine. }\end{array}$ & First episode: returned to baseline. & $\begin{array}{l}\text { Huang et } \\
\text { al. }\end{array}$ \\
\hline
\end{tabular}

Abbreviations: $N / A$ not applicable, $I V I g$ intravenous immunoglobulin

nervous system or blood circulatory system and that $\mathrm{AE}$ was triggered by these autoantigens due to virus infection or over-fatigue.

Fourteen cases in 22 patients with anti-AMPAR encephalitis had tumors, such as lung cancer, thymoma, breast cancer, or ovarian teratoma, indicating that paraneoplastic autoimmunity plays a key role in the pathogenic mechanisms of anti-AMPAR encephalitis $[10,14]$. Our case is more likely paraneoplastic autoimmune encephalitis even if encephalitis emerged 2 years after thymoma diagnosis.
Anti-AMPAR encephalitis has been reported to be associated with other autoimmune antibodies, such as antibodies against ANA, dsDNA, cardiolipin, glutamic acid decarboxylase (GAD), CV2/CRMP5 and AChR $[5,6]$. $\mathrm{AChR} \mathrm{Ab}$ is also positive in our patient; however, the immune relationships between these antibodies and AMPAR Ab has not been thoroughly elucidated to date.

Based on the clinical outcome of our patient and review of the published literature, tumor removal with or without chemotherapy and radiotherapy may be applied to anti-AMPAR encephalitis with thymic 
tumors, and immunotherapy including corticosteroids, IVIg and plasma exchange during presentation or relapse and chronic treatment with rituximab or azathioprine may prevent relapse and improve outcomes. In patients with anti-AMPAR encephalitis, oncological screening is mandatory with a particular focus on the thymus, lung and breast [12].

There are several limitations to our study. A more intense oncological screening and long-term follow-up is needed to determine whether the patient has other tumors or metastatic tumors in addition to thymoma.

In conclusion, we presented a case in which a thymectomy was applied in a myasthenia gravis patient with thymoma two years prior to the onset of anti-AMPAR2 encephalitis. This case highlights the complexity of autoimmune encephalitis associated with thymoma.

\section{Abbreviations}

AE: Autoimmune encephalitis; AMPAR: a-amino-3-hydroxy-5-methyl-4isoxazolepropionic acid receptor; AMPAR2: AMPAR GlUR2; CSF: Cerebrospinal fluid; Flair: Fluid-attenuated inversion recovery; GABA: $\gamma$-aminobutyric acid; MG: Myasthenia gravis; MMSE: Mini-Mental State Examination

\section{Acknowledgments}

We gratefully thank the participant and her families.

\section{Authors' contributions}

QYL, XHW and WH were all directly involved in the clinical management of this case. QYL and XHW was a major contributor in writing the manuscript under the guidance of WH. All authors read and approved the final manuscript.

\section{Funding}

Data collection, analysis, and interpretation of the study were supported by grants from the Natural Science Foundation of Guangxi Province (CN) (2017GXNSFAA198042).

\section{Availability of data and materials}

Data generated during this study are included in this published article.

\section{Ethics approval and consent to participate}

Not applicable.

\section{Consent for publication}

Written informed consent was obtained from the patient for publication of this Case Report and any accompanying images.

\section{Competing interests}

The authors declare that they have no competing interests.

\section{Author details}

'Department of Neurology, The First Affiliated Hospital of Guangxi Medical University, \#6 Shuangyong Road, Nanning 530021, Guangxi, China. ${ }^{2}$ Vasculocardiology, First Affiliated Hospital, Guangxi Medical University, Nanning, People's Republic of China530021.

Received: 18 November 2018 Accepted: 6 June 2019

Published online: 13 June 2019

\section{References}

1. Lancaster E, Martinez-Hernandez E, Dalmau J. Encephalitis and antibodies to synaptic and neuronal cell surface proteins. Neurology. 2011;77(2):179-89.

2. van Sonderen A, Schreurs MW, Wirtz PW, Sillevis Smitt PA, Titulaer MJ. From VGKC to LGI1 and Caspr2 encephalitis: the evolution of a disease entity over time. Autoimmun Rev. 2016;15(10):970-4.
3. Simabukuro MM, Petit-Pedrol M, Castro LH, Nitrini R, Lucato L, Zambon AA, et al. GABAA receptor and LGI1 antibody encephalitis in a patient with thymoma. Neurol Neuroimmunol Neuroinflamm. 2015;2(2):e73.

4. Irani SR, Alexander S, Waters P, Kleopa KA, Pettingill P, Zuliani L, et al. Antibodies to Kv1 potassium channel-complex proteins leucine-rich, glioma inactivated 1 protein and contactin-associated protein-2 in limbic encephalitis, Morvan's syndrome and acquired neuromyotonia. Brain. 2010;133(9):2734-48.

5. Lai M, Huijbers MG, Lancaster E, Graus F, Bataller L, Balice-Gordon R, et al. Investigation of $L G \mid 1$ as the antigen in limbic encephalitis previously attributed to potassium channels: a case series. Lancet Neurol. 2010;9(8):776-85.

6. Li X, Mao YT, Wu JJ, Li LX, Chen XJ. Anti-AMPA receptor encephalitis associated with thymomatous myasthenia gravis. J Neuroimmunol. 2015;281:35-7.

7. Lai M, Hughes EG, Peng X, Zhou L, Gleichman AJ, Shu H, et al. AMPA receptor antibodies in limbic encephalitis alter synaptic receptor location. Ann Neurol. 2009;65(4):424-34.

8. Evoli A, Lancaster E. Paraneoplastic disorders in thymoma patients. J Thorac Oncol. 2014;9(9 Suppl 2):S143-7.

9. Graus F, Boronat A, Xifro X, Boix M, Svigelj V, Garcia A, et al. The expanding clinical profile of anti-AMPA receptor encephalitis. Neurology. 2010;74(10):857-9.

10. Hoftberger R, van Sonderen A, Leypoldt F, Houghton D, Geschwind M, Gelfand J, et al. Encephalitis and AMPA receptor antibodies: novel findings in a case series of 22 patients. Neurology. 2015;84(24):2403-12.

11. Omi T, Kinoshita M, Nishikawa A, Tomioka T, Ohmori K, Fukada K, et al. Clinical relapse of anti-AMPAR encephalitis associated with recurrence of Thymoma. Intern Med. 2018:57(7):1011-3.

12. Joubert B, Kerschen P, Zekeridou A, Desestret V, Rogemond V, Chaffois MO, et al. Clinical Spectrum of encephalitis associated with antibodies against the alpha-Amino-3-Hydroxy-5-Methyl-4-Isoxazolepropionic acid receptor: case series and review of the literature. JAMA neurology. 2015;72(10):1163-9.

13. Hor JY, Lim TT, Cheng MC, Chia YK, Wong CK, Lim SM, et al. Thymomaassociated myasthenia gravis and LGI1-encephalitis, with nephrotic syndrome post-thymectomy. J Neuroimmunol. 2018;317:100-2.

14. Liu R, Dar AR, Tay KY, Nicolle MW, Inculet RI. Thymoma-associated myasthenia gravis in a young adult with development of paraneoplastic limbic encephalitis and systemic lupus erythematosus post-thymectomy: a case report. Cureus. 2018;10(11):e3581.

\section{Publisher's Note}

Springer Nature remains neutral with regard to jurisdictional claims in published maps and institutional affiliations.
Ready to submit your research? Choose BMC and benefit from:
- fast, convenient online submission
- thorough peer review by experienced researchers in your field
- rapid publication on acceptance
- support for research data, including large and complex data types
- gold Open Access which fosters wider collaboration and increased citations
- maximum visibility for your research: over $100 \mathrm{M}$ website views per year
At BMC, research is always in progress.
Learn more biomedcentral.com/submissions 